\title{
Influence of pineapple extract on physicochemical characteristics of cooked glutinous rice
}

\author{
Minh Phuoc Nguyen \\ Faculty of Biotechnology, Ho Chi Minh City Open University, Ho Chi Minh City, Vietnam \\ *Email: minh.np@ou.edu.vn
}

\section{ARTICLE HISTORY}

Received: 05 August 2020

Accepted: 11 September 2020

Published: 01 October 2020

\section{KEYWORDS}

Cooking time; gel consistency; glutinous rice; pineapple extract; phytic acid; soaking; volume increase ratio; water uptake ratio
ABSTRACT

Glutinous rice is an important crop in Southeast Asia. Pineapple had numerous potential to turn into added value. This research evaluated the impact of pineapple extract on physicochemical characteristics of cooked glutinous rice. The glutinous rice was soaked with pineapple extract in different percentage (0-2.5\%) at ambient temperature for $12 \mathrm{hrs}$ before cooking. The cooked glutinous rice was evaluated for gel consistency, water uptake ratio, volume increase ratio, cooking time and phytic acid content. Results showed that pineapple extract reduced gel consistency, cooking time, phytic acid while accelerating water uptake ratio, volume increase ratio. By incorporation of pineapple extract to glutinous rice during soaking, the physicochemical properties of cooked glutinous rice would be improved.

\section{Introduction}

Glutinous rice (Oryza sativa L.) is considered as one of the major sources of nutrients providing carbohydrates, proteins, fats, fibres, minerals, vitamins beneficial for daily consumption (1). It is commonly consumed in domestic and export due to its superior qualities of fineness, aroma, taste and protein content. Moreover, it contained excellent amount of phytochemical constituents like tocopherols, tocotrienols, $\gamma$-oryzanol and phenolic compounds existing in the outer pericarp and aleurone layers covering the grains contributing to functional benefits of human health (2-4). Soaking was a hydration process in which water diffused into rice grains, essential for the complete gelatinization of starch. It's critical as it modified the gross composition and distribution of nutrients within grains (5-7). Soaking caused the leaching of minor rice components in the soaking water $(5,6,8)$. Soaking changed protein, fat, amylopectin, fibre, ash and mineral compositions in glutinous rice $(1,5,8,9)$. Soaking also diffuses colour pigments, fat globules from husk and bran layers into starchy endosperm $(5,10)$. Pineapple (Ananas comosus (L.) Merr.) is one of the most popular agricultural products in the world due to its excellent flavour and taste, diversified valuable nutritional components as well as phytochemical and antioxidant properties (11). Pineapple pulp is clear yellow, very sweet, compact, fibrous, and has a high ascorbic acid content but low total acidity (12). Bromelain in pineapple is beneficial for the digestive system in maintaining ideal weight and balanced nutrition (13). Moreover, it's useful as an anti-inflammatory agent as well as swelling relief in inflammatory against acute sinusitis, sore throat, arthritis, gout (14). The objective of our study is to evaluate the impact of pineapple extract during soaking glutinous rice on physicochemical characteristics of the cooked product.

\section{Materials and Methods}

\section{Material}

The glutinous rice was collected from Nga Nam district, Soc Trang province, Vietnam. Pineapple fruit was harvested from Hau Giang province, Vietnam. Chemical reagents were all analytical grade purchased from Toan Thang Chemicals Company, Can Tho City, Vietnam.

(c) Nguyen (2020). This is an open-access article distributed under the terms of the Creative Commons Attribution License, which permits unrestricted use, distribution and reproduction in any medium, provided the original author and source are credited (https://creativecommons.org/licenses/by/4.0/).

To cite this article: Nguyen M P. Influence of pineapple extract on physicochemical characteristics of cooked glutinous rice. Plant Science Today. 2020;7(4):590-593. https://doi.org/10.14719/pst.2020.7.4.893 


\section{Researching method}

Pineapple fruit was washed thoroughly in clean water to remove dirt and foreign matter. It was pressed to collect juice extract. Each $500 \mathrm{gm}$ of glutinous rice was soaked in $1000 \mathrm{~mL}$ of fresh water at ambient temperature for $12 \mathrm{hrs}$ with pineapple extract supplementation in different percentage $(0$ $2.5 \%)$. After treatment, glutinous rice was drained on sieve before cooking at $100{ }^{\circ} \mathrm{C}$ for 45 minutes and analyzing physicochemical properties such as gel consistency, water uptake ratio, volume increase ratio, cooking time and phytic acid content.

\section{Physicochemical determination}

Gel consistency (mm) was determined by the standard method (15). Water uptake ratio was measured following the standard procedure described (6). Volume increase ratio and cooking time (min) were determined as described (16). Phytic acid (mg/g) was evaluated by spectrophotometer model Evolution 350 UV-Vis (17).

\section{Statistical analysis}

The experiments were run in 594 samples, with nine different groups of samples. The data were presented as mean \pm standard deviation. Statistical analysis was performed by the Statgraphics Centurion version XVI.

\section{Results and Discussion}

The gel consistency of the samples is clearly presented (Fig. 1). Significant differences were

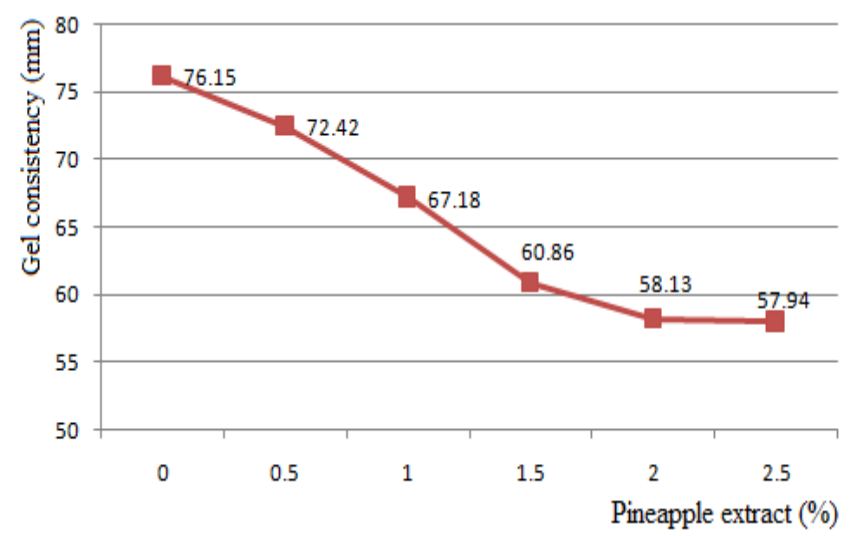

Fig. 1. Gel consistency (mm) of glutinous rice affected by pineapple extract (\%).

recorded between the treated samples in terms of a gel consistency. The lowest gel consistency value (58.13 $\mathrm{mm}$ or $57.94 \mathrm{~mm}$ ) belonged to the glutinous rice treated by $2.0 \%$ or $2.5 \%$ pineapple extract respectively. Gel consistency was an important chemical indicator reflecting the density of cooked glutinous rice. It directly influenced the firmness or softness of cooked glutinous rice. It could be explained by the reaction of bromelain. Bromelain supported in the digestion of proteins, working to break proteins down into amino acids. If the gel consistency was weak, the cooked glutinous rice tended to be sticky. A weak gel consistency implied that the cooked glutinous rice was soft and this was preferred. Glutinous rice with a strong gel consistency was considerably undesirable (18). The gel consistency of some rice varieties ranged from 6 to $100 \mathrm{~mm}$ (16). $\mathrm{NaCl}$ concentration and vacuum impregnation increased the hardness of parboiled rice (19). Soaking with $\mathrm{NaCl}$ and acetic acid significantly increased the grain hardness adhesiveness of cooked grains than normal watersoaked and un-soaked parboiled rice (20). The water uptake ratio of the glutinous rice samples, which were treated by pineapple extract ranged from 2.853.12 and the difference was statistically significant (Fig. 2). The enhancement of water uptake with an increase in pineapple extract could be attributed to water absorption of proteins in the glutinous rice.

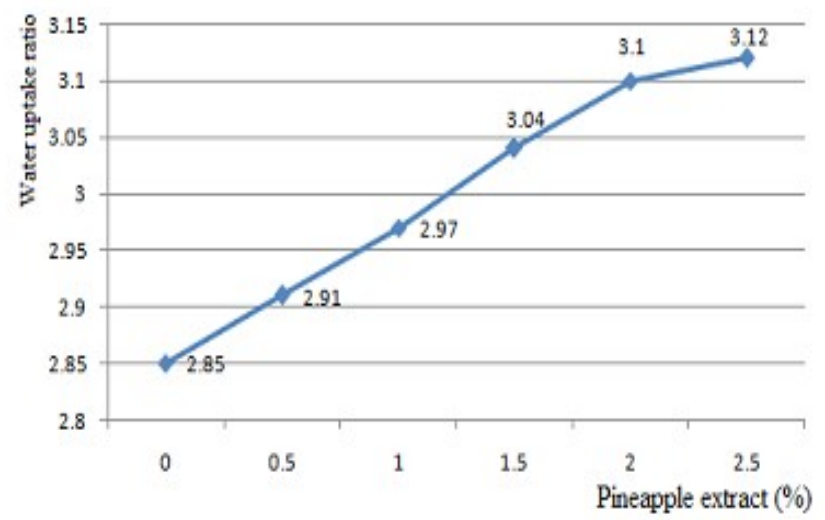

Fig. 2. Water uptake ratio of glutinous rice affected by pineapple extract (\%).

This might be explained owing to high concentration bromelain induced the reduction of hydrogen bonding at the protein surface. High pressureinduced water uptake is characteristics of Thai glutinous rice (21). One report examined the cooking and edible quality of Ofada rice.

The water uptake ratio was noticed between 1.74-2.11 (22). NaCl concentration and vacuum impregnation decreased the water uptake of parboiled glutinous rice (19). Meanwhile, the water uptake ratio ranged between $2.50-3.60$ on 15 rice samples in Turkey (18).

Volume increase ratio of the glutinous rice samples which were treated by pineapple extract ranged from 1.03-1.24 and the difference was statistically significant (Fig. 3). The magnitude of volume expansion was linearly related to the amount

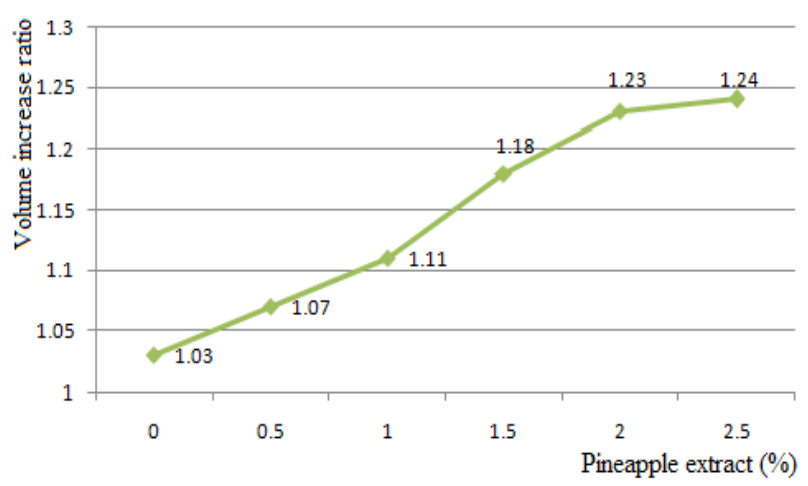

Fig. 3. Volume increase ratio of glutinous rice affected by pineapple extract (\%). 
of water uptake (23-25). The water uptake ratio increased with the decrease in the cooking temperature, indicating a higher rate of moisture diffusion (26). The volume increase ratio to be between 1.22-1.91 on rice (27). The volume increase ratio ranged from 1.08-1.24 taken on local Karacadag rice (Oryza sativa L.) - Turkey (18). Cooking time for rice was the time when $90 \%$ of the starch in the grain no longer show opaque centre when pressed between two glass plates $(22,28)$. Cooking time (min) of the glutinous rice samples which were treated by pineapple extract ranged from 17-22 min., and the difference was statistically significant (Fig. 4). The shorter the cooking time, the better in terms of fuel

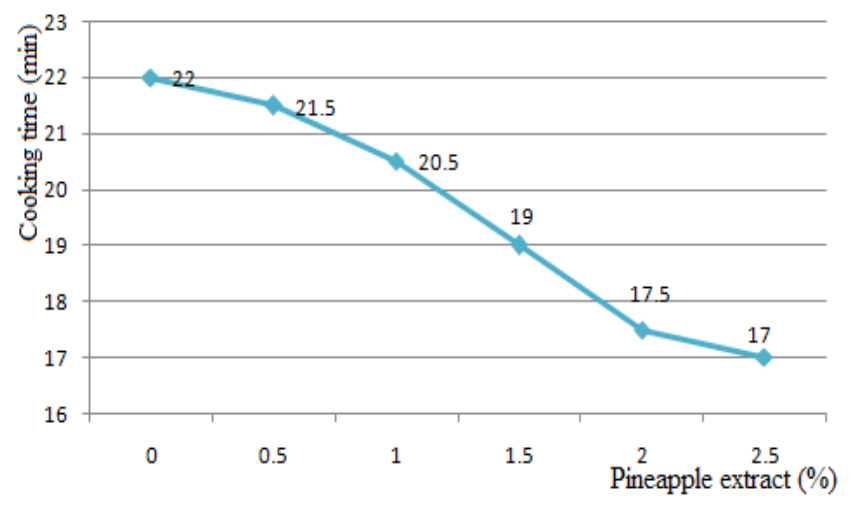

Fig. 4. Cooking time (min) of glutinous rice affected by pineapple extract $(\%)$.

and energy consumption during cooking. Reduced cooking time could be beneficial especially when fuel consumption was of concern (9). Cooking time was 52 and $56 \mathrm{~min}$ in two local rice varieties with local names Offada (white variety) and Alaso-osun (brown variety) (29). The cooking time was defined in the range of $13.3-24 \mathrm{~min}$ on 23 rice samples from India (30). The cooking time differed among varieties from Benin ranged from 20-26 min (16). Amylose content in glutinous rice could influence the cooking attributes (29). High amylose and long-chain amylopectin could lead to strong firmness, and viceversa with a weak texture on cooking. Rice, with higher amylose content, required shorter cooking time (9). Glutinous rice kernels treated with $\mathrm{Na}_{2} \mathrm{CO}_{3}$ had lower gelatinization temperature than untreated one (30). The cooking time was in the range of 16-19 min on 15 rice samples from Karacadag - Turkey (18). There was a significant difference $(p<0.05)$ among the treated samples in terms of their phytic acid content as shown (Fig. 5). The lowest amount of phytic acid $(2.61 \mathrm{mg} / \mathrm{g}$ or $2.43 \mathrm{mg} / \mathrm{g})$ was noticed in the glutinous rice sample treated by $2.0 \%$ or $2.5 \%$ pineapple extract respectively compared to $7.69 \mathrm{mg} / \mathrm{g}$ in the control sample. Phytic acid had a negative impact on human health by creating a complex with essential minerals, phosphorous and amino acids, therefore, preventing their absorption into the human body $(18,31,32)$. Pineapple extract had significant degradation of phytic acid in glutinous rice during soaking. Intermediate soaking temperatures would be useful for soaking of glutinous rice (33).

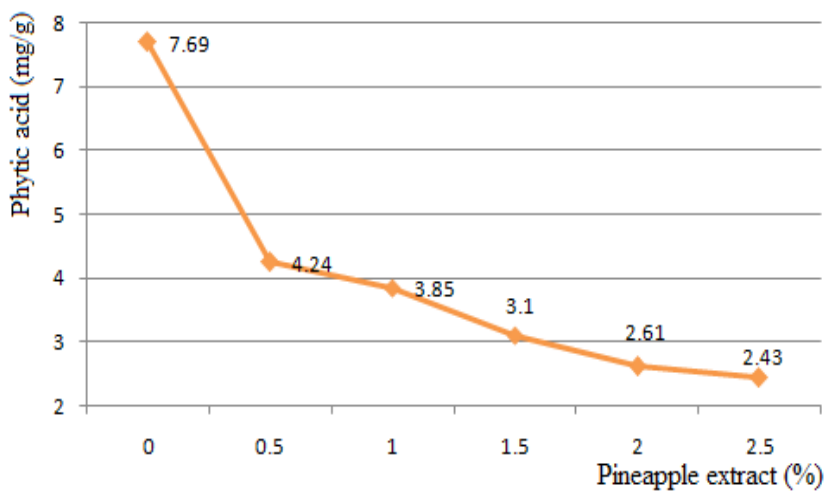

Fig. 5. Phytic acid (mg/g) content of glutinous rice affected by pineapple extract (\%).

\section{Conclusion}

The pineapple is a wonderful tropical crop having specific juiciness, distinct tropical flavour and numerous health benefits. This study showed that the pineapple extract in soaking medium significantly affected the physicochemical properties of glutinous rice. Pineapple extract submersed in glutinous rice reduced gel consistency, cooking time, phytic acid while enhancing water uptake ratio, volume increase ratio. It's desirable for glutinous rice to have a low amount of phytic acid. Current findings proved the potential of pineapple extract in improving the physicochemical quality of glutinous rice.

\section{Acknowledgements}

We acknowledge the financial support for the publication provided by Ho Chi Minh City Open University, Vietnam.

\section{Conflict of interests}

The authors declared that the present study was performed in the absence of any conflict of interest.

\section{References}

1. Heinemann RJB, Fagundes PL, Pinto EA, Penteado MVC, Lanfer-Marquez UM. Comparative study of nutrient composition of commercial brown, parboiled and milled rice from Brazil. J Food Comp Anal. 2005;18:287-96. https://doi.org/10.1016/j.jfca.2004.07.005

2. Qureshi A, Sami SA, Salser WA, Khan FA. Dose-dependent suppression of serum cholesterol by tocotrienol-rich fraction (TRF25) of rice bran in hypercholesterolemic humans. Atherosclerosis 2002;161:199-07. Available from: https://www.natrieo.com/resourcess/cardiovascular-health/

3. Loypimai P, Moongngarm A, Chottanom P. Effects of ohmic heating on lipase activity, bioactive compounds and antioxidant activity of rice bran. Aust J Basic Appl. 2009; 3:3642-52. https://www.researchgate.net/publication/267797316

4. Tiwari U, Cummins E. Nutritional importance and effect of processing on tools in cereals. Trends Food Sci Technol. 2009;20:511-20. https://doi.org/10.1016/j.tifs.2009.06.001

5. Otegbayo BO, Osamuel F, Fashakin JB. Effect of parboiling on physico-chemical qualities of two local rice varieties in Nigeria. J Food Technol Afr 2001; 6: 130-32. https://www.researchgate.net/publication/216731926 
6. Sareepuang K, Siriamornpun S, Wiset L, Meeso N. Effect of soaking temperature on physical, chemical and cooking properties of parboiled fragrant rice. World J Agric Sci. 2008; 4 : 409-15. https://www.researchgate.net/publication/265990443

7. Mir SA, Bosco SJD. Effect of soaking temperature on physical and functional properties of parboiled rice cultivars grown in temperate region of India. Food Nutr Sci. 2013;4:282-88. https://doi.org/10.4236/fns.2013.43038

8. Ibukun EO. Effect of prolonged parboiling duration on proximate composition of rice. Sci Res Essay. 2008;3:323-25. https://www.researchgate.net/publication/238066486

9. Thomas R, Wan-Nadiah WA, Bhat R. Physiochemical properties, proximate composition, and cooking qualities of locally grown and important rice varieties marketed in Penang, Malaysia. International Food Research Journal. 2013; 20:1345-51. http://www.ifrj.upm.edu.my/20\%20(03)\%202013/4 5\%20IFRJ\%2020\%20(03)\%202013\%20Rajeev\%20(303).pdf

10. Dutta H, Mahanta CL. Effect of hydrothermal treatment varying in time and pressure on the properties of the parboiled rices with different amylose content. Food Res Int 2012; 49: 655-63. https://doi.org/10.1016/j.foodres.2012.09.014

11. Nguyen PM, Tran TYN, Danh DNH, Vo MC. Quality and shelf life of processed pineapple by different edible coatings. Journal of Pharmaceutical Sciences and Research. 2019; 11:1441-46. https://www.jpsr.pharmainfo.in/Documents/Volum es/vol11issue04/jpsr11041950.pdf

12. Minh NP. Synergistic effect of calcium chloride and chitosan treatment on physicochemical characteristics of pineapple (Ananas comosus) fruit during cool storage. International Journal of Lifescience and Pharma Research. 2020;10:24-28. http://dx.doi.org/10.22376/ijpbs/lpr.2020.10.3.L24-28

13. Vipul C, Vivak K, Sunil V, Kavindra S, Ratnesh K, Vikrant K. Pineapple (Ananas cosmosus) product processing: A review. Journal of Pharmacognosy and Phytochemistry. 2019;8: 4642. https://www.researchgate.net/publication/333867227

14. Tanmay S, Pritha N, Runu C. Pineapple [Ananas comosus (L.)] product processing techniques and packaging: A review. IIOABJ. 2018;9:6-12. https://www.researchgate.net/profile/Tan may_Sarkar6publication340776043

15. Oko AO, Ubi BE, Dambaba N. Rice cooking quality and physicochemical characteristics: a comparative analysis of selected local and newly introduced rice varieties in Ebonyi State, Nigeria. Food and Public Health. 2012;2:43-49. https://doi.org/10.5923/j.fph.20120201.09

16. Fofana M, Futakuchi K, Manful JT, Yaou IB, Dossou J, Bleoussi RTM. Rice grain quality: a comparison of imported varieties, local varieties with new varieties adopted in Benin. Food Control. 2011;22:1821-25. https://doi.org/10.1016/j.foodcont.2011.04.016

17. Haug W, Lantzsch HJ. Sensitive method for the rapid determination of phytate in cereals and cereal products. Journal of the Science of Food and Agriculture 1983;34:1423-26. https://doi.org/10.1002/jsfa.2740341217

18. Koten M, Unsal AS, Kahraman S. Physicochemical, nutritional, and cooking properties of local Karacadag rice (Oryza sativa L.) - Turkey. International Food Research Journal. 2020;27:43544. http://www.ifrj.upm.edu.my/27\%20(03)\%202020/DONE\%20 \%2005\%20-\%20IFRJ20011.R1.pdf

19. Patiwit L, Kulab S, Anuchita M, Wilawan P. Influence of sodium chloride and vacuum impregnation on the quality and bioactive compounds of parboiled glutinous rice. J Food Sci
Technol.

2017:54:1990-98.

https://link.springer.com/article/10.1007/s13197-017-2635-3

20. Malik AN, Shu F, Sangeeta P, Bhesh B. Effect of soaking medium on the physicochemical properties of parboiled glutinous rice of selected Laotian cultivars. International Journal of Food Properties. 2018;21:1896-10. https://doi.org/10.1080/10942912.2018.1503301

21. Ahromrit A, Ledward DA, Niranjan K. High pressure induced water uptake characteristics of Thai glutinous rice. Journal of Food Engineering. 2006;72:225-33. https://doi.org/10.1016/j.jfoodeng.2004.11.013

22. Danbaba N, Anounye JC, Gana AS, Abo ME, Ukwungwu MN Grain quality characteristics of ofada rice (Oryza sativa L.): cooking and eating quality. International Food Research Journal. 2011;18:629-34. http://www.ifrj.upm.edu.my/18(02)2011/(23)IFRJ-2010-105.pdf

23. Muthukumarappan K, Jindal VK, Gunasekaran S. Volumetric changes in rice kernels during desorption and adsorption. Transactions of the ASAE. 1992;35:235-41. https://doi.org/10.13031/2013.28593

24. Bhattacharya S. Kinetics of hydration of raw and roasted corn semolina. Journal of Food Engineering. 1995;25:21-30. https://doi.org/10.1016/0260-8774(95)93013-1

25. Bello M, Tolaba MP, Suarez C. Factors affecting water uptake of rice grain during soaking. LWT-Food science and Technology. 2004;37:811-16. https://doi.org/10.1016/j.lwt.2004.02.014

26. Elizabeth DW, Sayyad A, Manuj KH. Water uptake in brown rice during soaking for production of no-cooking rice. AgricEngInt: CIGR Journal. 2019;21:138-49. https://cigrjournal.org/index.php/Ejounral/article/view/4608

27. Koca AF, Anıl M. Quality characteristics and evaluation of rice. Journal of Ondukuz Mayls University. 2001;16:103-08. https://doi.org/10.1016/j.tifs.2019.07.039

28. Dipti SS, Bari MN, Kabir KA. Grain quality characteristics of some beruin rice varieties of Bangladesh. Pakistan Journal of Nutrition. https://doi.org/10.3923/pjn.2003.242.245

2003;2:242-45

29. Singh N, Kaur L, Singh SN, Sekhon KS. Physicochemical, cooking and textural properties of milled rice from different Indian rice cultivars. Food Chemistry. 2005;89:253-59. https://doi.org/10.1016/j.foodchem.2004.02.032

30. Kunyarat R, Sanguansri C. Effect of sodium carbonate on appearance and textural properties of glutinous rice cake. International Journal of Food Science and Technology. 2013;48:2185-92. https://doi.org/10.1111/ijfs.12203

31. Egli I, Davidson L, Zeder C, Walczyk T, Hurrell R. Dephytinization of a complementary food based on wheat and soy increases zinc, but not copper, apparent absorption in adults. The Journal of Nutrition. 2004;134:1077-80. https://doi.org/10.1093/jn/134.5.1077

32. Wang KM, Wu JG, Li G, Zhang DP, Yang ZW, Shi CH. Distribution of phytic acid and mineral elements in three Indica rice (Oryza sativa L.) cultivars. Journal of Cereal Science. 2011;54:16-21. https://doi.org/10.1016/j.jcs.2011.03.002

33. Kale SJ, Jha SK, Jha GK, Sinha JP, Lal SB. Soaking induced changes in chemical composition, glycemic index and starch characteristics of Basmati rice. Rice Science. 2015;22:227-36. https://doi.org/10.1016/j.rsci.2015.09.002 